\title{
Endocrine disturbances related to the use of lithium
}

\author{
Distúrbios endocrinológicos relacionados ao uso de lítio
}

Cecília F. Giusti', Soraya R. Amorim', Ricardo A. Guerra', Evandro S. Portes'

\section{SUMMARY}

Despite recent advances in pharmacological treatment of psychiatric disorders, lithium salts remain frequently used, as they are effective and inexpensive alternatives, especially in the treatment of bipolar disorders. Their use is commonly associated with various endocrine disorders, mainly in thyroid and parathyroid function, and in mineral metabolism. This article aims at reviewing these potential endocrinopathies related to the use of lithium to make health care professionals aware and familiar with these possible complications when they follow up patients using this drug, and to make them able to monitor, identify and institute early and appropriate treatment. Arq Bras Endocrinol Metab. 2012;56(3):153-8

\section{Keywords}

Lithium; hypercalcemia; diabetes insipidus; goiter

\section{SUMÁRIO}

Apesar dos recentes avanços farmacológicos no tratamento dos transtornos psiquiátricos, os sais de lítio permanecem como uma alternativa eficaz e de menor custo, sendo usados com frequência principalmente no tratamento dos transtornos bipolares. 0 seu uso é comumente relacionado com diversas alterações endocrinológicas, principalmente nas funções tiroidiana, paratiroidiana e do metabolismo iônico. Este artigo tem por objetivo fazer uma revisão dessas potenciais endocrinopatias relacionadas ao uso do lítio, para que, no seguimento de pacientes em uso dessa medicação, os profissionais de saúde estejam atentos e familiarizados com essas possíveis complicações, conseguindo identificar e instituir tratamento precocemente. Arq Bras Endocrinol Metab. 2012;56(3):153-8

Descritores

Lítio; hipercalcemia; diabetes insipidus; bócio

\author{
${ }^{1}$ Serviço de Endocrinologia, \\ Hospital do Servidor \\ Público Estadual (HSPE), \\ São Paulo, SP, Brazil
}

Correspondence to: Cecília F. Giusti Rua Pedro de Toledo, 1800 9o andar central 04039-004 - São Paulo, SP, Brazil ceciliagiusti@hotmail.com

Received on Sept/13/2011 Accepted on Mar/6/2012

\section{INTRODUCTION}

L ithium salts were introduced into medical therapy in the mid-19th century, with reports of their use in migraine prophylaxis, and in the treatment of psychiatric disorders, gout and neutropenia $(1,2)$. Currently, they are available in immediate- and extended-release formulas and are used to treat mania, refractory and recurrent depression and bipolar disorders with reduced morbidity and mortality. Despite recent advances in pharmacological treatment of psychiatric disorders, these salts remain effective and inexpensive alternatives $(3,4)$.

Lithium can promote major endocrine and metabolic disturbances, mainly in thyroid and parathyroid functions, and in the mineral metabolism (5). This review article will discuss the main endocrine disorders related to the use of lithium salts.

\section{PHARMACOLOGICAL ASPECTS}

The exact mechanism by which lithium acts as a mood stabilizer is still unknown. Many molecular and cellular activities are involved in its neuroprotective and neurotropic properties. Due to an inhibition of the calciuminflux mediating receptor $\mathrm{N}$-methyl $\mathrm{D}$-aspartate, lithium interferes with calcium homeostasis and suppresses the activation of pro-apoptotic calcium-dependent signal- 
ing pathways (6). It also seems to act in the modulation of neurotransmitters and reduce glutaminergic activity, contributing to neuroprotection. In addition, it modulates pathways that regulate neuronal plasticity, such as glycogen synthase kinase $3 \beta$, cAMP-dependent kinase and protein kinase $\mathrm{C}(7)$.

Because of lithium narrow therapeutic range and possible overdose potential, small elevations in its circulating levels may be associated with toxic reactions. Therefore, it is very important to monitor its plasma concentrations in patients under treatment. It is recommended that serum levels are assessed every 3-6 months (3). The therapeutic concentration that is considered safe ranges from $0.6-1.25 \mathrm{mEq} / \mathrm{L}$ but, when used for a long time, maximum levels of $0.75 \mathrm{mEq} / \mathrm{L}$ are preferable. The doses of lithium carbonate recommended to achieve this goal vary from 900 to 1,500 mg per day (1).

Lithium is absorbed rapidly and almost completely from the gastrointestinal tract. After an oral dose, absorption occurs in up to 8 hours and reaches its highest serum concentration in 2 to 4 hours. Slow-release preparations reduce the rate of absorption and therefore the peak plasma level. Once absorbed, lithium reaches the extracellular fluid and gradually accumulates in the tissues. Because it is low protein bound, it is freely filtered by the kidneys and its excretion is dependent on glomerular filtration rate. About $95 \%$ of the ingested dose is excreted in the urine without undergoing biotransformation. Its half-life is up to 24 hours and may be longer in the elderly $(1,3)$. Approximately $80 \%$ of lithium is reabsorbed in the proximal renal tubules. The administration of massive doses of sodium leads to greater lithium elimination, while states of sodium depletion lead to a greater retention, increasing the risk of intoxication (8).

At therapeutic doses, nausea, diarrhea, weight gain, fine tremor of the hands, and skin lesions, especially acne and psoriasis, may happen (9). The major toxic effects related to the use of lithium are the cognitive disturbances, dysarthria, and impaired coordination. The most severe effects include mental confusion, hyperreflexia, gross tremor, focal neurologic signs, seizures, coma, and even death $(1,3)$. Other toxic effects include albuminuria, hypotension, and cardiac arrhythmias. Electrocardiographic alterations include prolongation of the QT interval, and changes in the ST segment and T wave (10).

\section{DISTURBANCES IN THE ENDOCRINE SYSTEM}

\section{Mineral metabolism}

Chronic use of lithium is generally associated with mild hypercalcemia, which is usually reversible with the withdrawal of the medication. However, in some cases, there may be persistent hypercalcemia, and even the development of hyperparathyroidism, by means of a still unknown mechanism (11).

The addition of lithium to parathyroid cells cultures (both normal and hyperplasic) causes an increase in PTH levels from 1.4 to 5.3 times. In vivo, several experiments demonstrated that lithium interferes with the dynamics of PTH secretion by increasing the setpoint of parathyroid calcium-sensing receptor. By shifting the $\mathrm{PTH} /$ calcium secretion curve to the right, higher levels of serum calcium are required to inhibit PTH secretion, thus increasing calcemia and PTH levels (1214). Lithium also promotes reduced urinary excretion of calcium due to increased renal resorption secondary to PTH increase (15).

The prevalence of hyperparathyroidism associated with lithium is higher in women $(4: 1)$, with the occurrence of both parathyroid adenomas and hyperplasia. The best approach must be individually evaluated in each case since there is no exact recommendation on the best surgical procedure in these cases (16). As an alternative to surgery, especially in cases of persistent hyperparathyroidism, the use of calcium mimetic agent (Cinacalcet) has been reported with good results (17).

A recent review and meta-analysis about lithium toxicity profile recommends that calcium concentrations should always be checked before and during lithium treatment (18).

\section{Thyroid}

Some patients treated with lithium may develop thyroid enlargement. Induction of thyroid cell growth is reported even in ectopic thyroids (19). This goitrogenic potential can be manifested in up to $50 \%$ of patients taking lithium chronically. Generally, it is diffuse, painless, and benign goiter (20).

Concerning lithium interference with the regulation of thyroid cell proliferation, there are conflicting descriptions about its inhibitory effect on the cAMP pathway $(21,22)$. Therefore, the Wnt/B-catenin pathway assumes an emerging role in these regulatory mechanisms. By inhibiting GSK3B (glycogen synthase 
kinase B), an enzyme that degrades B-catenin, lithium can simulate a functional activation of this molecular signaling pathway, which has a functional relevance for the regulation of thyroid cell proliferation, as an alternative to the cAMP pathway (23).

Inhibition of the release of thyroid hormones is the main mechanism involved in hypothyroidism and goiter related to lithium use. It is unclear how patients who will develop goiter can be identified. Generally, women and patients with detectable thyroid antibodies before starting to use lithium are more likely to develop thyroid abnormalities. The prevalence of goiter is higher in patients using the medication for long periods and in those living in iodine-deficient areas. The interval between starting treatment and the onset of goiter may vary from a few weeks to several years. The risk of thyroid cancer is not increased in these patients (24-26).

The presence of autoimmune thyroiditis predisposes to hypothyroidism and goiter during treatment with lithium, with a relative risk of 8.4 compared with patients with negative antibodies (27). However, the exact role of autoimmunity in thyroid failure induced by the drug remains uncertain. In addition, there is controversy about the effects of the drug in inducing thyroid autoimmunity (28). Gland involvement may occur even in the absence of autoantibodies, showing that thyroid dysfunction can exist independently of the autoimmune process (29). Instead of inducing autoimmunity, lithium appears to stimulate secretion of immunoglobulins by lymphocytes, triggering a pre-existing immune response (28). Autoimmune thyroid disease precipitated by lithium also appears to be related to an interference with the function of CD8 suppressor cells (30).

Lithium accumulates in thyroid tissue against a concentration gradient, by active transport. This cation reduces iodine uptake by the thyroid gland, interfering with tyrosine iodination, changing thyroglobulin structure and colloid formation in the apical pole of thyroid cells, thus interfering with iodotyrosine synthesis (Figure 1). It also inhibits deiodinase 2, leading to a decrease in T3 pituitary concentrations (31). Treatment with lithium may also lead to a hyper-response of TSH in the TRH test (32). Up to $30 \%$ of patients chronically treated with lithium develop increased TSH (subclinical hypothyroidism) that may progress to overt hypothyroidism, with or without goiter (33).

Lithium inhibition of thyroid iodine uptake is reversible and dose-dependent (35). This inhibition is more pronounced in patients with hyperthyroidism.

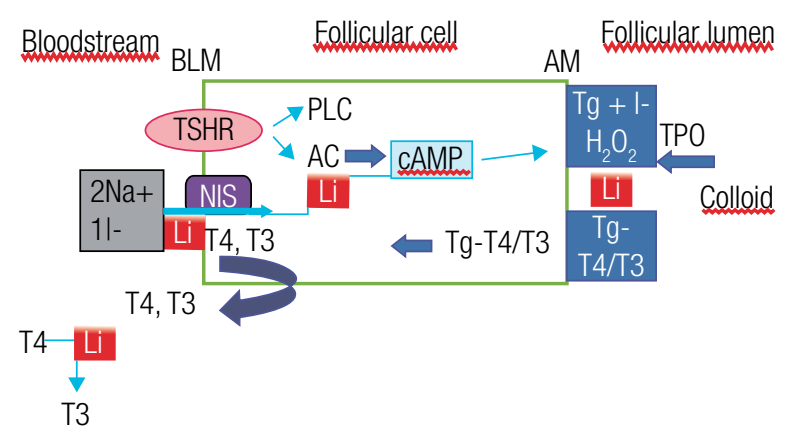

BLM: basolateral membrane; AM: apical membrane; PLC: phospholipase C; AC: adenylate cyclase; CAMP: cyclic adenosine monophosphate; TPO: thyroperoxidase; Tg: thyroglobulin; T4: thyroxine; T3: triiodothyronine; Li: lithium; $\mathrm{Na}^{+}$: sodium; I: iodide; NIS: sodium-iodide symport; TSHR: TSH receptor.

Figure 1. Main points involved in lithium-induced thyroid dysfunction. Adapted from: Williams Textbook of Endocrinology. 11 $1^{\text {th }}$ edition. 2008 (34).

Lithium in low doses is used as a therapeutic alternative in thyrotoxicosis patients who cannot tolerate or do not respond to thyonamides (36). Another therapeutic use is the association of lithium and radioactive iodine in the treatment of Graves' disease. Several series show that this association leads to a more rapid control of thyrotoxicosis, increasing therapeutic efficacy when compared with radioiodine alone, due to the inhibition of radioiodine release by the thyroid (37). Silent thyroiditis and thyrotoxicosis have been less frequently reported after long-term lithium use, possibly as a direct effect of the drug on follicular cells (38).

A rare report is the occurrence of Hashimoto's encephalopathy triggered by lithium, with increased antimicrossomal antibody titers in cerebrospinal fluid, reflecting the exposure the thyroid and central nervous system to common antigens (39).

Thyroid function, antithyroid antibodies and ultrasound of the gland are recommended before starting lithium therapy, with repeated screenings at regular intervals during treatment (26).

It is important to note that the presence of abnormalities in thyroid function is not an absolute contraindication to the use of lithium, neither its discontinuation is required in the eventual onset of thyroid disturbances during lithium treatment. The management of thyroid dysfunction can be done even with the maintenance of lithium therapy, but the risks and benefits of such approach always have to be assessed (26). 


\section{Nephrogenic diabetes insipidus}

Arginine-vasopressin or antidiuretic hormone $(\mathrm{ADH})$ is secreted by the hypothalamus, stored, and released by the posterior pituitary. This hormone plays a key role in the control of body fluids. Its signaling mechanism is mediated by $\mathrm{G}$ protein-coupled receptors and is directly related to increased intracellular cAMP.

The ability of the kidneys to retain water and concentrate urine is regulated by $\mathrm{ADH}$, the osmolality of the renal medulla, appropriate sodium transport and the function of aquaporins (40). Aquaporins are water channels inside of proteins expressed in renal tubules and collecting ducts. The greater the activation of aquaporins, the greater water reabsorption in renal collecting ducts, reducing the volume of urine. When the expression of aquaporins is inhibited, polyuria ensues. Nephrogenic diabetes insipidus (NDI) is characterized by renal inability to concentrate urine, even in the presence of normal concentrations of $\mathrm{ADH}$, causing a clinical polyuric syndrome.

The binding of the $\mathrm{ADH}$ to the $\mathrm{V} 2$ receptor stimulates the expression of aquaporins in the kidney (4l). Lithium inhibits the expression of these aquaporins in the renal collecting duct, mainly aquaporin 2 (AQP2), by mechanisms still not fully understood (42). Most studies show an inhibition of adenylate cyclase activity (43). However it has already been demonstrated in animal models that lithium-induced downregulation of AQP2 is independent of cAMP and adenylate cyclase, and is related to the reduction of AQP2 m-RNA synthesis (42), inhibition of adenosine triphosphatases, and interference with prostaglandin production (44). Lithium enters the collecting tubule cells via highly selective sodium and lithium channels, located in the apical membrane, causing increased sodium excretion and decreased renal tubule responsiveness to aldosterone and ADH. These channels are stimulated by aldosterone and inhibited by amiloride (45).

Up to $20 \%$ to $40 \%$ of patients chronically treated with lithium may develop NDI. Lithium use of the most common cause of acquired NDI $(42,46)$, which is usually reversible after the withdrawal of the drug. However, in some cases it takes several months or years for the full re-establishment of the renal ability to concentrate urine (47). After prolonged use, even with discontinuation of the drug, some patients may have irreversible kidney damage due to a chronic interstitial nephropathy, with reports of evolution to end-stage re- nal failure (46), but the absolute risk seems to be small ( $0.5 \%$ compared with $0.2 \%$ in the general population) as shown by a recent review (18). In order to prevent renal toxicity, besides monitoring serum lithium and creatinin levels, a single daily dose of lithium should be preferred (46).

Thiazide diuretics are a therapeutic option in NDI, but hydrochlorothiazide has the potential to increase lithium toxicity, so it should be used with caution in these cases. Amiloride would be a better option because, besides its natriuretic action (causing contraction of extracellular volume, consequent decrease in glomerular filtration, and ultimately leading to decreased urine volume), it also reduces the entry of lithium in distal tubule cells (40). It is also important to be aware of the possibility of the coexistence of NDI and hypercalcemia related to lithium, since dehydration can exacerbate hypercalcemia. Another treatment option is a nonsteroidal antiinflammatory drug, such as indomethacin, but it should not be carried out on a long-term basis due to its side effects (46).

\section{Hypothalamic-pituitary-adrenal axis}

A study with patients in treatment for major depression showed that lithium led to an increased ACTH and cortisol response in the combined dexamethasone-CRH test, suggesting a possible effect of the drug on the hypothalamic-pituitary-adrenal axis (48).

In vitro studies demonstrate that lithium can inhibit apoptosis of human adrenal cortex, both in normal tissues and in tumors (49). On the other hand, lithium also inhibited the proliferation of pheochromocytoma cells by inhibiting the enzyme GSK3B (glycogen synthase kinase $3 \beta$ ), and promoting the suppression of chromogranin A, which represents a novel potential strategy for developing treatments of catecholaminergic tumors $(50)$.

\section{Glucose metabolism}

Lithium has an inhibitory effect on amino acid- and glucose-induced insulin secretion by means of mechanisms related to microtubular function and calcium influx in pancreatic beta cells (51). Studies in rats showed that intravenous infusion of lithium leads to hyperglycemia, increased levels of glucagon and lower insulin response induced by both glucose and tolbutamide (52). These effects can be attributed to the action of catecholamines in the sympathetic-adrenal system, pro- 
moting glycogenolysis, and to the direct effect of the drug on pancreatic alpha- 2 and beta-adrenergic receptors, determining the reduction of insulin secretion and increased levels of glucagon (53).

On the other hand, lithium has also been associated with an insulin-like effect on glucose metabolism in skeletal muscle and adipocytes. In rat muscles, the drug increased the sensitivity of insulin-induced glucose transport, similar to the effects of exercise (54). Animal models also show that lithium promotes greater uptake of glucose by myocytes and glycogen synthesis, involving phosphorylation of AKT, GSK-3 inhibition, and increased p38-MAPK (mitogen-activated protein kinase) as mechanisms of action (55).

\section{Effects on body weight}

Weight gain up to $10 \mathrm{~kg}$ can occur in almost $30 \%$ of patients using lithium (44), by means of a mechanism that is still unclear, making therapy management more difficult (56). One possibility may be related to the stimulation of a greater intake of high-calorie beverages, especially in patients with polydipsia $(44,57)$. Some studies also show changes in leptin levels, which ultimately can be involved in weight gain (58).

\section{CONCLUSION}

Considering all these aspects related to the use of lithium, it is important to be aware and familiar with all these potential endocrine disturbances when patients using this medication are followed up. Adequate monitoring is essential in order to identify possible complications and, thus, institute early and appropriate treatment.

Disclosure: no potential conflict of interest relevant to this article was reported.

\section{REFERENCES}

1. Baldessarini RJ, Tarazi FI. Tratamento farmacológico da psicose e da mania. In: Brunton LL, Lazo JS, Parker KL, eds. Goodman e Gilman: As bases farmacológicas da terapêutica. 11.ed. Rio de Janeiro: MacGraw-Hill. 2006; p. 411-46.

2. Freeman MP, Freeman SA. Lithium: clinical considerations in internal medicine. Am J Med. 2006;119:478-81.

3. Collins N, Barnes TR, Shingleton-Smith A, Gerret D, Paton C. Standards of lithium monitoring in mental health trusts in the UK. BMC Psychiatry. 2010;10:80.

4. Simhandl C, Mersch J. [Lithium and bipolar disorder - a renaissance?]. Neuropsychiatr. 2007;21(2):121-30.

5. Kusalic M, Engelsmann F. Effect of lithium maintenance therapy on thyroid and parathyroid function. J Psychiatry Neurosci. $1999 ; 24(3): 227-33$.
6. Chiu CT, Chuang DM. Molecular actions and therapeutic potential of lithium in preclinical and clinical studies of CNS disorders. PharmacolTher. 2010;128(2):281-304.

7. Jope RS. Anti-bipolar therapy: mechanism of action of lithium. Mol Psychiatry. 1999;4(2):117-28.

8. Thomsen K, Shirley DG. A hypothesis linking sodium and lithium reabsorption in the distal nephron. Nephrol Dial Transplant. 2006;21(4):869-80.

9. Chan HH, Wing Y, Su R, Van Krevel C, Lee S. A control study of the cutaneous side effects of chronic lithium therapy. J Affect Disord. 2000;57:107-13.

10. Kayrak M, Ari H, Duman C, Gul EE, Ak A, Atalay H. Lithium intoxication causing STsegment elevation and wandering atrial rhythms in an elderly patient. Cardiol J. 2010;17(4):404-7.

11. Hundley JC, Woodrum DT, Saunders BD, Doherty GM, Gauger PG. Revisiting lithium associated hyperparathyroidism in the era of intraoperative parathyroid hormone monitoring. Surgery. 2005;138(6):1027-31.

12. Birnbaum J, Klandorf $H$, Giuliano A, Van Herle A. Lithium stimulates the release of human parathyroid hormone in vitro. $\mathrm{J}$ Clin Endocrinol Metab. 1987;66:1187-91.

13. Mallette LE, Khouri K, Zengotita H, Hollis BW, Malini S. Lithium treatment increases intact and midregion parathyroid hormone and parathyroid volume. J Clin Endocrinol Metab. 1988;68:654-60.

14. Haden ST, Stoll AL, McCormick S, Scott J, Fuleihan GE. Alterations in parathyroid dynamics in lithium-treated subjects. J Clin Endocrinol Metab. 1997;82:2844-8.

15. Mak TW, Shek CC, Chow CC, Wing YK, Lee S. Effects of lithium therapy on bone mineral metabolism: a two-year prospective longitudinal study. J Clin Endocrinol Metab. 1998;83:3857-9.

16. Szalat A, Mazeh H, Freund HR. Lithium-associated hyperparathyroidism: report of four cases and review of the literature. Eur $\mathrm{J}$ Endocrinol. 2009;160(2):317-23.

17. Sloand JA, Shelly MA. Normalization of Ilithium-induced hypercalcemia and hyperparathyroidism with cinecalcet hydrochloride. Am J Kidney Dis. 2006;489(5):832-7.

18. McKnight RF, Adida M, Budge K, Stockton S, Goodwin GM, Geddes JR. Lithium toxicity profile: a systematic review and meta-analysis. Lancet. 2012;379:721-8.

19. Talwar N, Mohan S, Ravi B, Andley M, Kumar A. Lithium-induced enlargement of a lingual thyroid. Singapore Med J. 2008;49(3):254-5.

20. Bauer M, Blumentritt $H$, Finke R, Schlattman P, Adli M, Baethge C, et al. Using ultrasonography to determine thyroid size and prevalence of goiter in lithium-treated patients with affective disorders. J Affect Disord. 2007;104(1-3):45-51.

21. Mori M, Tajima K, Oda Y, Matsui I, Mashita K, Tarui S. Inhibitory effect of lithium on the release of thyroid hormones from thyrotropin-stimulated mouse thyroids in a perifusion system. Endocrinology. 1989;124:1365-9.

22. Urabe M, Hershman J, Pang XP, Murakami S, Sugawara M. Effect of lithium on function and growth of thyroid cells in vitro. Endocrinology. 1991;129:807-14.

23. Rao AS, Kremenevskaja N, Resch J, Brabant G. Lithium stimulates proliferation in cultured thyrocytes by activating Wnt/B-catenin signaling. Eur J Endocrinol. 2005;153:929-38.

24. Esposito S, Prange AJ Jr, Golden RN. The thyroid axis and mood disorders: overview and future prospects. Psychopharmacol Bull. 1997;33:205-17.

25. Henry C. Lithium side effects and predictors of hypothyroidism in patients with bipolar disorder: sex differences. J Psych Neuroscience. 2002;27:104-7.

26. Bocchetta A, Loviselli A. Lithium treatment and thyroid abnormalities. Clin Pract Epidemiol Ment Health. 2006;2:23. 
27. Bocchetta A, Cocco F, Velluzzi F, Del Zompo M, Mariotti S, Loviselli A. Fifteen-year follow-up of thyroid function in lithium patients. J Endocrinol Invest. 2007;30(5):363-6.

28. Loviselli A, Bocchetta A, Mossa P, Velluzi F, Bernardi F, Del Zompo $M$, et al. Value of thyroid echography in the long term follow-up of Lithium Treated Patients. Neuropsychobiol. 1997;36:37-41.

29. Baethge $C$, Blumentritt $H$, Berhöfer A, BschorT, Glenn T, Adli M, et al. Finke R. Long-term lithium treatment and thyroid antibodies: a controlled study. J Psychiatry Neurosci. 2005;30:423-7.

30. Cooper DS, Greenspan FS, Ladenson PW. Thyroid gland. In: Gardner DG, Shoback D, eds. Greenspan's Basic \& Clinical Endocrinology. 8th edition. NewYork: Lange/McGraw-Hill; 2007. p. 232.

31. Germain DLS. Regulatory effect of lithium on thyroxine metabolism in murine neural and anterior pituitary tissue. Endocrinology. 1986;120:1430-8.

32. Livingstone $\mathrm{C}$, Rampes $\mathrm{H}$. Lithium: a review of its adverse metabolic effects. J Psychopharmacol. 2006;20(3):347-55.

33. Fagiolini A, Kupfer DJ, Scott J, Swartz HA, Cook D, Novick DM, et al. Hypothyroidism in patients with bipolar disorder treated primarily with lithium. Epidemiol Psichiatr Soc. 2006;15(2):123-7.

34. Larsen PR, Davies TF, Schlumberger MJ, Hay ID. Thyroid physiology and diagnostic evaluation of patients with thyroid disorders. In: Kronenberg HM, Melmed S, Polonsky KS, Larsen PR, eds. Williams Textbook of Endocrinology. 11th Edition. Philadelphia: WB Saunders Company. 2008;299-332.

35. TsuchiyaY, Saji M, Isozaki O, Arai M,TsushimaT, Shizume K. Effect of lithium on deoxyribonucleic acid synthesis and iodine uptake in porcine thyroid cells in culture. Endocrinology. 1990;126:460-5.

36. Ng YW, Tiu SC, Choi KL, Chan FK, Choi CH, Kong PS, et al. Use of lithium in the treatment of thyrotoxicosis. Hong Kong Med J. 2006;12(4):254-9.

37. Bogazzi F, Bartalena L, Brogioni S, Scarcella G, Burelli A, Campomoro $A$, et al. Comparison of radioiodine with radioiodine plus lithium in the treatment of graves hyperthyroidism. J Clin Endocrinol Metab. 1999;84:499-503.

38. Pearce EM, Farwell AP, Braverman LE. Thyroiditis. N Engl J Med. 2003;348:2646-55.

39. Nagamine M, Yoshino A, Ishii M, Ogawa T, Kurauchi S, Yoshida T, et al. Lithium-induced Hashimoto's encephalopathy: a case report. Bipolar Disord. 2008;10(7):846-8.

40. Robinson AG. Posterior pituitary. In: Gardner DG, Shoback D, eds. Greenspan's Basic \& Clinical Endocrinology. 8th edition. Lange McGraw-Hill; 2007. p. 164.

41. Naves LA, Vilar L, Costa ACF, Domingues L, Casulari LA. Disturbances in the secretion and action of antidiuretic hormone. Arq Bras Endocrinol Metab. 2003;47:347-57.

42. LiY, Shaw S, Kamsteeg EJ, Vandewalle A, Deen PMT. Development of lithium-induced nephrogenic diabetes insipidus is dissociated from adenyl cyclase activity. J Am Soc Nephrol. 2006;17:1063-72.

43. Jackson BA, Edwards RM, Dousa TP. Lithium-induced polyuria: effect of lithium on adenylate cyclase and adenosine 3' 5 '-mono- phosphate phosphodiesterase in medullary ascending limb of Henle's loop and in medullary collecting tubules. Endocrinology. 1980;107:1693-8.

44. Grandjean EM, Aubry JM. Lithium: update human knowledge using an evidence-based approach: part III: Clinical Safety. CNS Drugs. 2009;23:397-418.

45. Nielsen J, Kwon TH, Frokiaer J, Knepper MA, Nielsen S. Lithium-induced NDI in rats is associated with loss of alpha-ENaC regulation by aldosterone in CCD. Am J Physiol Renal Physiol. 2006;290(5):F1222-33.

46. Le Roy V, DelmasY, Verdoux H. Chronic renal complications induced by lithium. Encephale. 2009;35(6):605-10.

47. Reeves WB, Bichet DG, TE Andreolli. The posterior pituitary and water metabolism. In: Wilson JD, Fotser DW, Kronemberg HM, Larsen PR, eds. Williams Textbook of Endocrinology. 9th Edition. Philadelphia:WB Saunders Company; 2003; p. 341-8.

48. Bschor T, Adli $M$, Baethge $C$, Eichmann $U$, Ising $M$, Uhr $M$, et al. Lithium augmentation increases the ACTH and cortisol response in the combined DEX/CRH test in unipolar major depression. Neuropsychopharmacology. 2002;27:470-8.

49. Pushkarev VM, Tronko ND, Kostyuchenko NN, Mikoshi AS. Effect of o, $p^{\prime}$-DDD and $\mathrm{Li}+$ on apoptotic DNA fragmentation in conventionally normal and tumour tissues of human adrenal cortex. Ukr Biokhim Zh. 2007;79(2):44-9.

50. Kappes A, Vaccaro A, Kunnimalaiyaan M, Chen H. Lithium ions: a novel treatment for pheochromocytomas and paragangliomas. Surgery. 2007;141(2):161-5.

51. Anderson JH Jr, Blackard WG. Effect of lithium on pancreatic islet insulin release. Endocrinology. 1978;102:291-5.

52. Shah JH, Pishdad G. The effect of lithium on glucose and tolbutamide-induced insulin release and glucose tolerance in the intact rat. Endocrinology. 1980;107:1300-4.

53. Hermida OG, Fontela T, Ghiglione M, Uttenthal LO. Effect of Iithium on plasma glucose, insulin and glucagon in normal and streptozotocin-diabetic rats: role of glucagon in the hyperglycaemic response. Br J Pharmacol. 1994;111:861-5.

54. Tabata I, Schluter J, Gulve EA, Holloszy OJ. Lithium Increases susceptibility of muscle glucose transport to stimulation by various agents. Diabetes. 1994;43(7):903-7.

55. Macko AR, Benez AN, Teachey MK, Henriksen EJ. Roles of insulin signaling and p38 MAPK activation by lithium in the transport of glucose in insulin-resistant rats skeletal muscle. Arch Physiol Biochem. 2008;114:331-9.

56. Baptista T, Teneud L, Contreras $\mathrm{O}$, Sprawl T, Burquera J, Burque $M$, et al. Lithium and body weight gain. Pharmacopsychiatry. 1995;28(2):35-44.

57. Chen Y, Silverstone T. Lithium weight gain. Int Clin Psychopharmacol. 1990;5(3):217-25.

58. Atmaca M, Kuloglu M, Tezcan E, Ustundag B. Weight gain ad serum leptin levels in patients on lithium treatment. Neuropsychobiology. 2002;46:67-9. 